\title{
Otolith-based age determination of mid-Burdigalian marine sediments in the North Alpine Foreland Basin
}

\author{
ClAudia TESCHNER \& BetTINA REICHENBACHER
}

\begin{abstract}
Precise age constraints are rare for the Oligocene to Miocene sediments in the North Alpine Foreland Basin, also referred to as Molasse Basin. This is mainly due to the lack of index fossils, absence of continuous outcrops and scarcity of radiometrically datable rocks. In this study, we applied the Sr isotope dating technique to fossil teleost fish otoliths to determine absolute ages for Lower Miocene (mid-Burdigalian, lower Ottnangian) marine sediments. The fossil otoliths from the marine genera Diaphus and Coelorinchus used in our analysis were recovered from the Neuhofen Beds in the SE German Molasse Basin. For the first time, leaching experiments were conducted on different otolith fractions to extract the ambient ${ }^{87} \mathrm{Sr} /{ }^{86} \mathrm{Sr}$ seawater signal. Based on the latest version of the evolution curve for the ${ }^{87} \mathrm{Sr} /{ }^{86} \mathrm{Sr}$ ratio in the global ocean, our new data suggest an age of $17.1 \pm 0.3 \mathrm{Ma}$, which is at least $0.6 \mathrm{~m}$.y. younger than hitherto assumed for the Neuhofen Beds based on biostratigraphy and lithostratigraphic correlations. We suggest that strong riverine inputs could account for this shift in the Sr isotope signal to younger ages. - Key words: Sr isotopes, fossil otoliths, biostratigraphy, chronostratigraphy, chemostratigraphy, Central Paratethys, Upper Marine Molasse.
\end{abstract}

TESCHNER, C. \& REICHENBACHER, B. 2017. Otolith-based age determination of mid-Burdigalian marine sediments in the North Alpine Foreland Basin. Bulletin of Geosciences 92(2), 143-152 (3 figures, 1 table). Czech Geological Survey, Prague. ISSN 1214-1119. Manuscript received January 1, 2017; accepted in revised form May 5, 2017; published online June 27, 2017; issued June 30, 2017.

Claudia Teschner \& Bettina Reichenbacher, Department of Earth and Environmental Sciences, LudwigMaximilians-Universität, D-80333 Munich,Germany; c.teschner@posteo.de, b.reichenbacher@lrz.uni-muenchen.de

The establishment of high-resolution age models for sedimentary successions is crucial for numerous research questions in the geosciences and related disciplines. Such models provide an absolute chronology that permits accurate dating of depositional episodes and related processes such as mountain uplift or climate change (see Gradstein 2012). Particularly in epicontinental settings, precise age estimates are often compromised by lateral and transverse changes in lithofacies and an absence of marine index fossils. The North Alpine Foreland Basin is a case in point. Here, the lack of continuous outcrops and the scarcity of volcanic ash or bentonites that provide radiometric ages render precise correlation of the sediments with the Global Time Scale difficult (see Abdul Aziz et al. 2010; Grunert et al. 2013, 2015; Reichenbacher et al. 2013; Roetzel et al. 2014; Pippèrr \& Reichenbacher 2017; Sant et al. 2017).

The North Alpine Foreland Basin (NAFB) developed during the late Eocene and persisted as an important sedimentary basin of Central Europe until the late Miocene (e.g. Lemcke 1988). It extended from Lake Geneva through Southern Germany to Lower Austria, where it merges with the Carpathian Foredeep. The mainly siliciclastic sediments of the NAFB, usually referred to as
'Molasse', derive largely from the Alps. Other important sediment suppliers were the Franconian Platform, composed of Jurassic limestone, and the Bohemian Massif with its granitic rocks (Kuhlemann \& Kempf 2002) (Fig. 1). The thickness of the sediments in the NAFB ranges from a few tens of metres in the north to $4000 \mathrm{~m}$ close to the Alps (Lemcke 1988).

Analysis of the $\mathrm{Sr}$ isotopic composition of fossil biogenic material is a well-established method for age determination. It is based on both the conservative behaviour of the ${ }^{87} \mathrm{Sr} /{ }^{86} \mathrm{Sr}$ ratio in the ocean and its long-term trend throughout the Phanerozoic (McArthur et al. 2012). Sr has a long ocean residence time on the order of several million years, which ensures its homogenous distribution in the oceans (Palmer \& Edmond 1989). Over the course of the Phanerozoic, the ${ }^{87} \mathrm{Sr} /{ }^{86} \mathrm{Sr}$ ratio in seawater changed as a consequence of fluctuations in weathering intensities resulting from orogenies, climate change (Qing et al. 1998) and increased hydrothermal input during phases of continental break-up (Palmer \& Edmond 1989). In addition, variations in salinity levels - in marginal marine environments, for example - can result in local offsets in the ${ }^{87} \mathrm{Sr} /{ }^{86} \mathrm{Sr}$ signal (e.g. Ingram \& Sloan 1992, Bryant et al 1995, Reinhardt et al. 2003). 
Age reconstructions based on $\mathrm{Sr}$ isotope ratios in the NAFB have relied mainly on fish teeth (Vennemann \& Hegner 1998, Vennemann et al. 2001, Kocsis et al. 2009), although the technique has also been applied to ostracods (Janz \& Vennemann 2005) and otoliths (Pippèrr et al. 2007). The Sr isotope data obtained in these studies are not always easy to interpret because some reveal a significant offset with respect to the global seawater $\mathrm{Sr}$ evolution curve due to e.g. diagenetic overprints (Kocsis et al. 2009). In the present work, we asked whether $\mathrm{Sr}$ isotope analysis of well-preserved fossil fish otoliths from an epi- to mesopelagic environment in the NAFB could provide less ambiguous age estimates.

\section{Geological setting}

The NAFB is part of the Western and Central Paratethys domain. For the latter, regional chronostratigraphic stages have been introduced, because the presence of a largely endemic fauna and flora hinders accurate stratigraphic correlation with the Mediterranean area and the Global Time Scale (GTS) (e.g. Cicha et al. 1967, Papp et al. 1973, Steininger et al. 1976). The Burdigalian stage, to which this study refers, corresponds to the chronostratigraphic Central Paratethys stages of the Eggenburgian (except its lowermost part), Ottnangian and Karpatian (Piller et al. 2007).

The fish otoliths studied here were collected from a clay pit near the village of Mitterdorf, about $50 \mathrm{~km}$ northeast of Passau in Lower Bavaria, SE Germany (48 29' 56.23" N; $13^{\circ} 16^{\prime} 59.99^{\prime \prime}$ E) (Fig. 1). The diggings there have exposed an approximately 10-m thick succession of the middle Burdigalian Upper Marine Molasse (Obere Meeresmolasse, OMM) and, more specifically, of the Neuhofen Beds (NH Beds). The $\mathrm{NH}$ Beds can be assigned to the lower Ottnangian based on benthic foraminiferal stratigraphy (Wenger 1987, Pippèrr 2011) and are up to $220 \mathrm{~m}$ thick (Doppler et al. 2005). The sample material originates from the second mining floor of the outcrop, approximately $9 \mathrm{~m}$ above its base. Samples were taken from homogenous greyish to greyish-blue marls of the $\mathrm{NH}$ Beds with a low sand content.

\section{Materials and methods}

Material. - Otoliths are aragonitic concretions located in the inner ear of teleost fish, where they serve as balance and hearing organs (Popper 1976, Popper et al. 2005). Previous work has revealed that the otoliths of marine fishes reflect the isotopic signal of the surrounding seawater (e.g. Kennedy et al. 2000, 2002; Walther \& Thorrold 2006). Here we have used otoliths from the marine genera Diaphus (otolith lengths 1.5-2 mm) and Coelorinchus (otolith lengths 4-5 mm), which are known to thrive in epi- to mesopelagic environments. Diaphus is found at depths corresponding to those of continental shelves and slopes; it remains at 325-475 m during the day, and moves into shallower water (40-250 m) during the night (Hulley 1986). Coelorinchus is commonly found in about $200-500 \mathrm{~m}$ water depth (Cohen et al. 1990). We therefore assume that a clear open ocean $\mathrm{Sr}$ isotopic signal should be preserved in the otoliths of both Diaphus and Coelorinchus. Besides the otoliths we used bulk samples from the otolith-bearing sediment for $\mathrm{Sr}$ isotope analysis.

Processing of samples. - Nine well-preserved otoliths of both Diaphus and Coelorinchus were selected using the light orange colour and shiny gloss of the otoliths as indicators for unaltered material (see Pippèrr et al. 2007). To check whether the Sr isotope signal is consistent within the otolith samples, both intact and fragmented otoliths were analysed (Table 1). Three of the otolith samples used (O1, $\mathrm{O} 2, \mathrm{O} 3)$ were crushed between two glass slides prior to analysis, and fragments from both the core $(\mathrm{O} 1, \mathrm{O} 2)$ and the rim (O3) were separated. Two other otolith samples consisted of complete and structurally intact otoliths $(\mathrm{O} 4, \mathrm{O} 5)$. Each otolith sample was transferred to a $1.5-\mathrm{ml}$ centrifuge tube, and samples $\mathrm{O} 1-\mathrm{O} 4$ were subjected to a leaching procedure designed to remove adventitiously associated, mobile Sr that might have overprinted the ambient seawater signal of the otoliths during diagenesis. The leaching procedure was carried out with $200-\mu$ l aliquots of $0.25 \mathrm{M}$ acetic acid for a maximum of 20 minutes, replacing the supernatant every 2 minutes. After removal, each supernatant was transferred to a clean Teflon vial and dried on a hotplate with infrared light. The (residual) otolith material remaining after 20 minutes was dissolved in $6 \mathrm{M}$ hydrochloric acid. A total of 20 subsamples were obtained from otolith samples $\mathrm{O} 1-\mathrm{O} 4$ after the individual leaching steps (see Table 1). In addition, the two bulk samples (S1, S2, each c. $200 \mathrm{mg}$ ) were leached for 5 minutes with $500 \mu \mathrm{l}$ acetic acid $(0.25 \mathrm{M})$. All samples were centrifuged, the supernatant was dried down and $50 \mu$ l of concentrated nitric acid was added. Then the sample was dried again, and another $50 \mu \mathrm{l}$ of concentrated nitric acid was added. $\mathrm{Sr}$ was further purified on columns filled with $50 \mu \mathrm{l}$ of Sr-Spec resin (mesh 50-100) following the method of Horwitz et al. (1992) and Bayon et al. (2002).

Sr isotope analysis.- All Sr isotope analyses were carried out on a Spectromat-upgraded MAT 261 instrument (see Table 1). Strontium was loaded with $\mathrm{TaF}_{5}$ on single tungsten filaments. For mass-bias correction of the $\mathrm{Sr}$ isotope measurements ${ }^{86} \mathrm{Sr} /{ }^{88} \mathrm{Sr}=0.1194$ was applied (Steiger \& Jäger 1977), while also correcting for interference due to 


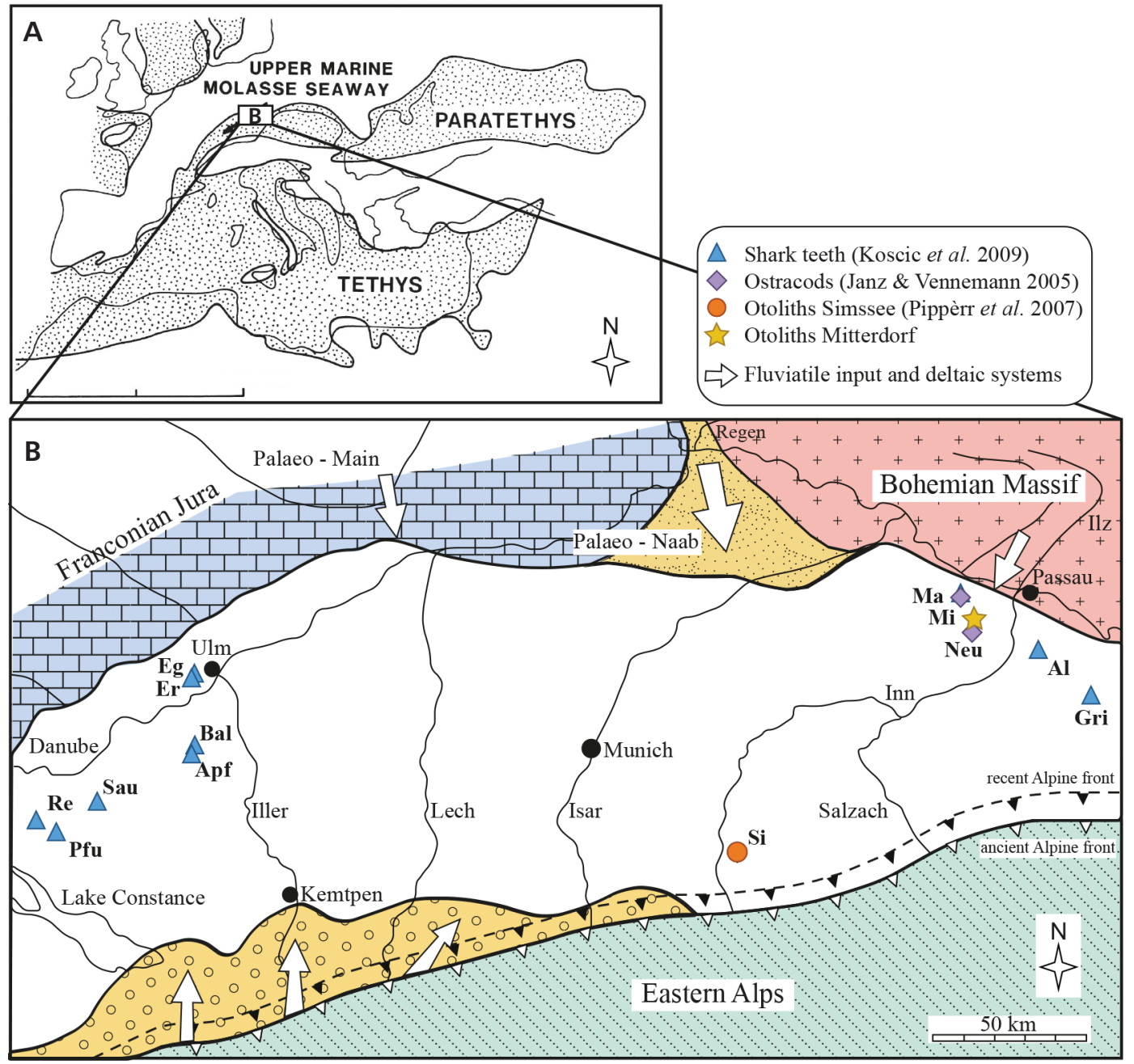

Figure 1. A - paleogeography of the Paratethys and Mediterranean Tethys during the Early Miocene (Ottnangian) (after Allen et al. 1985). $\bullet$ - map of the S German Molasse Basin during the early Ottnangian (modified after Pippèrr 2011, Kuhlemann \& Kempf 2002) showing the locations of previously studied sites. Abbreviations: Al - Allerding, Apf - Äpfingen, Bal - Baltringen, Eg - Eggingen, Er - Ermingen, Gri - Griesskirchen, Ma - Maierhof, $\mathrm{Mi}$ - Mitterdorf, Neu - Neuhofen, Pfu - Pfullendorf, Re - Rengetsweiler, Sau - Saulgau, Si - Simssee.

${ }^{86} \mathrm{Sr}$ and ${ }^{87} \mathrm{Rb}$. The $\mathrm{Sr}$ isotope results were normalized to ${ }^{87} \mathrm{Sr} /{ }^{86} \mathrm{Sr}=0.710248$ of the NIST SRM 987 standard (Jones et al. 1994), which was also used to derive the long-term reproducibility of the radiogenic $\mathrm{Sr}$ isotope measurements $(2 \sigma= \pm 11, \mathrm{n}=15)$ over 2 months.

\section{Results}

Both crushed and intact samples subjected to leaching yielded isotope ratios that declined from the starting values (up to ${ }^{87} \mathrm{Sr} /{ }^{86} \mathrm{Sr}=0.70876$ ) measured in the first supernatant (Table 1). After a leaching time of 20 minutes or less, the residues of the leached otolith samples (O1-O4) showed a consistent ${ }^{87} \mathrm{Sr} /{ }^{86} \mathrm{Sr}$ ratio $(0.708645 \pm 15)$ (Fig. 2). The error values were the same for all samples, regardless of taxon (Diaphus or Coelorinchus) and whether the otoliths were fragmented or complete. Sample O5 (which was not leached) gives an ${ }^{87} \mathrm{Sr} /{ }^{86} \mathrm{Sr}$ ratio of 0.708711 , indicating that it retains the mobile $\mathrm{Sr}$ phase that was removed during leaching of the other samples (Fig. 2). The leached fraction of the sediments, however, gave much lower radiogenic values $\left({ }^{87} \mathrm{Sr} /{ }^{86} \mathrm{Sr}=0.708612\right.$ and 0.708552 respectively) than the leach fractions and residues of any of the otolith samples (Fig. 2).

\section{Interpretation of Sr isotopic data}

The efficacy of the leach procedure is revealed by the consistency between the $\mathrm{Sr}$ isotopic compositions of the residues of all leached samples (O1-O4) and is supported by the fact that the ${ }^{87} \mathrm{Sr} /{ }^{86} \mathrm{Sr}$ ratio is much more radiogenic in the unleached otolith sample relative to the leached 
Table 1. Sr isotopic composition of the leached otoliths from Mitterdorf.

\begin{tabular}{|c|c|c|c|c|}
\hline Sample & & Leach time $(\min )$ & ${ }^{87} \mathrm{Sr} /{ }^{86} \mathrm{Sr}$ & Note \\
\hline \multirow[t]{3}{*}{ O1 (Diaphus sp.) } & Leachate & 2 & 0.708670 & \pm 16 Inner fragments of two crushed otoliths \\
\hline & Leachate & 6 & 0.708641 & \pm 14 \\
\hline & Leachate & 10 & 0.708642 & \pm 19 Sample was completely dissolved after $10 \mathrm{~min}$ \\
\hline \multirow[t]{5}{*}{$\mathrm{O} 2$ (Coelorinchus sp.) } & Leachate & 2 & 0.708745 & \pm 14 Inner fragments of one crushed otolith \\
\hline & Leachate & 6 & 0.708708 & \pm 12 \\
\hline & Leachate & 10 & 0.708677 & \pm 12 \\
\hline & Leachate & 14 & 0.708678 & \pm 13 \\
\hline & Residue & & 0.708645 & \pm 12 \\
\hline \multirow[t]{6}{*}{ O3 (Diaphus sp.) } & Leachate & 4 & 0.708680 & \pm 17 Rim fragments of two crushed otoliths \\
\hline & Leachate & 6 & 0.708663 & \pm 17 \\
\hline & Leachate & 8 & 0.708659 & \pm 19 \\
\hline & Leachate & 10 & 0.708653 & \pm 14 \\
\hline & Leachate & 12 & 0.708646 & \pm 19 \\
\hline & Residue & & 0.708639 & \pm 16 \\
\hline \multirow[t]{6}{*}{ O4 (Diaphus sp.) } & Leachate & 2 & 0.708764 & \pm 17 Two uncrushed otoliths \\
\hline & Leachate & 4 & 0.708748 & \pm 33 \\
\hline & Leachate & 8 & 0.708670 & \pm 15 \\
\hline & Leachate & 12 & 0.708668 & \pm 17 \\
\hline & Residue & & 0.708648 & \pm 22 \\
\hline & Residue & & 0.708651 & \pm 10 duplicate \\
\hline O5 (Diaphus sp.) & Residue & & 0.708711 & \pm 16 Two uncrushed otoliths, not leached \\
\hline S1 Sediment & Leachate & 5 & 0.708612 & \pm 13 \\
\hline S2 Sediment & Leachate & 5 & 0.708552 & $\pm 1310 \mathrm{~m}$ below $\mathrm{S} 1$, equal to $\mathrm{O} 4$ \\
\hline
\end{tabular}

samples (Fig. 2). Moreover, the residues of all leached samples show $\mathrm{Sr}$ isotope signals that are statistically indistinguishable from those extracted from ostracods from the NH Beds at the Neuhofen locality itself (Janz \& Vennemann 2005), which is not far from our study site (Fig. 1). This reinforces the reliability of our leaching procedure. Hence we assume that the ${ }^{87} \mathrm{Sr} /{ }^{86} \mathrm{Sr}$ ratio of 0.708645 (average of the residues of $\mathrm{O} 1-\mathrm{O} 4)$ reflects that of the ambient seawater at the time of deposition of the NH Bed at Mitterdorf. When compared with the recent global Sr seawater curve (LOWESS 5 Fit; McArthur et al. 2012), this Sr isotopic ratio indicates an age of $17.1 \pm 0.3 \mathrm{Ma}$ for the $\mathrm{NH}$ Beds (Fig. 3).

The values for the non-radiogenic isotope in the leach fractions from the two bulk sediments are, however, difficult to understand. Recent weathering effects of rain or groundwater may have overprinted the sediments (clays and silts) in the clay pit, which are now exposed to the elements. If so, the relative resistance of the otoliths to such effects may be attributable to their aragonitic composition. The increase in the non-radiogenic Sr signal in the sediment leach might also be due to the partial dissolution of a non-radiogenic fraction in the bulk sediment, e.g. sediment particles from the Franconian Jura or the Alps (see below).

\section{Discussion}

Previous work on ${ }^{87} \mathrm{Sr} /{ }^{86} \mathrm{Sr}$ signals from the Upper Marine Molasse (OMM)

Several studies have been carried out with a view to optimizing the extraction of radiogenic isotopes $(\mathrm{Nd}, \mathrm{Sr})$ from various biogenic materials derived from the North Alpine Foreland Basin (Vennemann \& Hegner 1998, Vennemann et al. 2001, Janz \& Vennemann 2005, Pippèrr et al. 2007, Kocsis et al. 2009) (see Figs 1, 3). Janz \& Vennemann (2005) analysed the Sr isotopic composition of ostracods from two locations (Maierhof and Neuhofen) not far from Mitterdorf, the site studied here (see Fig. 1). The OMM succession exposed at Maierhof corresponds to the middle Eggenburgian 'Ortenburger Sande' (see Witt 1967, Hagn et al. 1981, Pippèrr \& Reichenbacher 2009). The ostracod Cytheridea eggenburgensis from Maierhof provided an ${ }^{87} \mathrm{Sr} /{ }^{86} \mathrm{Sr}$ ratio of $0.708498 \pm 9$ (Janz \& Vennemann 2005). This yields an estimated age of 19 Ma based on the most recent global Sr seawater curve (LOWESS 5 Fit) (McArthur et al. 2012), which is compatible with the assumed age of the middle Eggenburgian (Piller et al. 2007) (Fig. 3). The OMM deposits at Neuhofen belong to the NH Beds, but are slightly older than the NH Beds at Mitterdorf (Pippèrr et al. 


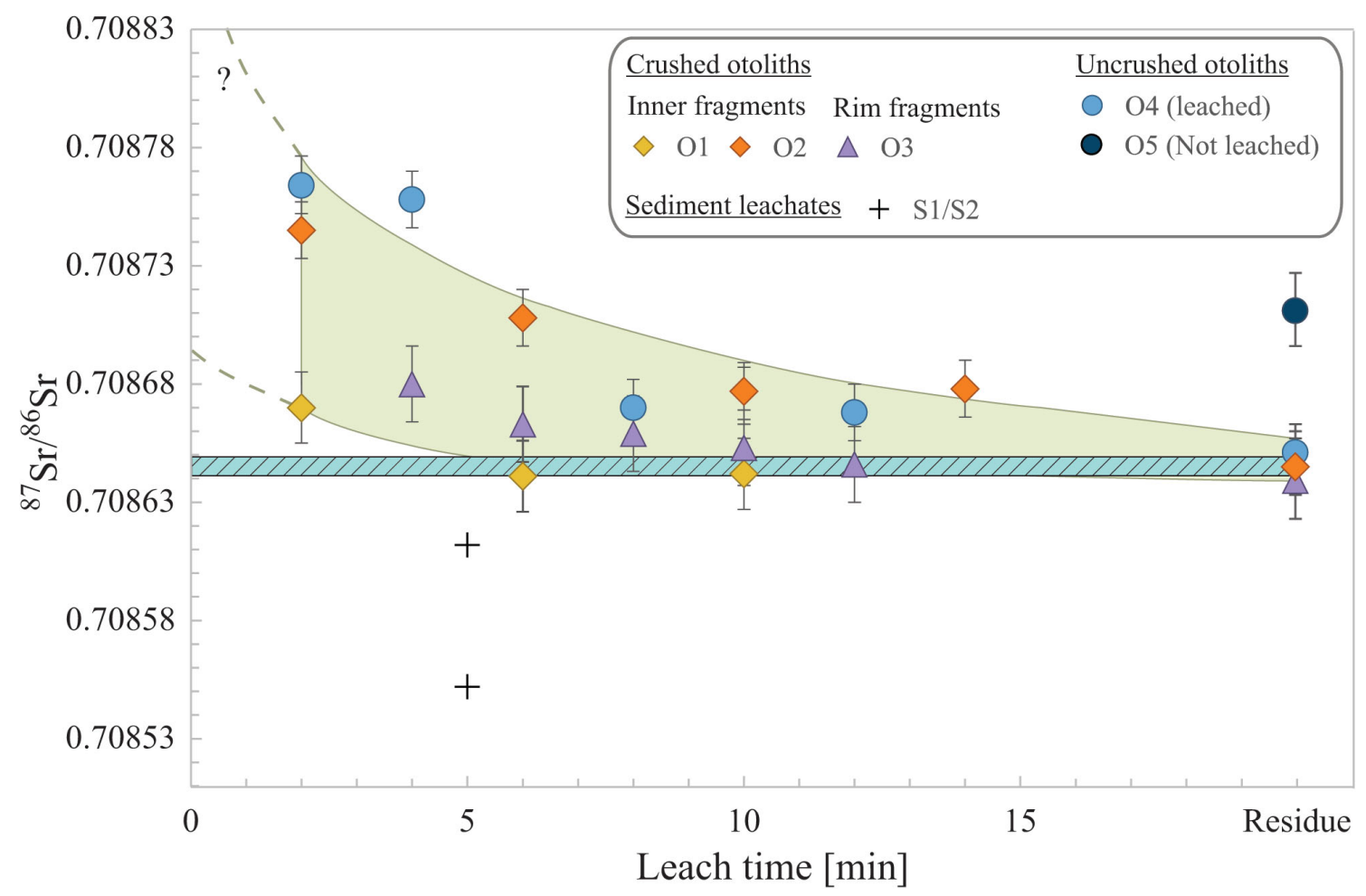

Figure 2. Effect of leaching time on the ${ }^{87} \mathrm{Sr} /{ }^{86} \mathrm{Sr}$ signal (light green shaded area) obtained from inner otolith fragments (yellow/orange diamonds), rim fragments of otoliths (lavender triangles) and the intact otolith sample (light blue circle). The dark blue circle illustrates the intact and untreated otolith sample O5. The hatched area marks the ${ }^{87} \mathrm{Sr} /{ }^{86} \mathrm{Sr}$ isotopic composition of the ambient seawater extracted from the otoliths after completion of the 20 -minute leaching procedure.

in press). The ostracod Cytheridea ottnangensis from Neuhofen yielded an ${ }^{87} \mathrm{Sr} /{ }^{86} \mathrm{Sr}$ value of $0.708624 \pm 10(\mathrm{Janz} \&$ Vennemann 2005), which is consistent with the values in the present work $(\mathrm{O} 1-\mathrm{O} 4,0.708645 \pm 15)$. In light of previous biostratigraphic work, which dated the NH Beds to the lower Ottnangian (c. $18 \mathrm{Ma}$ ) (Witt 1967, Hagn et al. 1981, Wenger 1987, Pippèrr 2011), the corresponding age of $17.1 \pm 0.3 \mathrm{Ma}$ indicated both by the results of our study and the aforementioned ostracod $C$. ottnangensis, appears to be at least $0.6 \mathrm{~m} . \mathrm{y}$. too young.

On the other hand, magnetostratigraphic evidence also suggests that previous biostratigraphic age estimates for the Ottnangian strata in the Molasse Basin of S Germany might be too high (Reichenbacher et al. 2013, Sant et al. 2017). According to these studies, the Kirchberg Formation, previously assumed to be upper Ottnangian in age and thus 17.2-17.4 Ma old, can now be correlated with the lower Karpatian, i.e. with the interval 16.7-17.2 Ma (Reichenbacher et al. 2013, Pippèrr \& Reichenbacher 2017, Sant et al. 2017 - age model 2) or the middle Karpatian, i.e. 16.4-16.5 Ma (Sant et al. 2017 - age model 1). This makes the allegedly 'upper Ottnangian' strata of the Kirchberg Fm 0.5 m.y. or even 0.8 m.y. younger than hitherto estimated. However, it is not yet clear whether the new age models affect previous age correlations for other
Ottnangian strata. It has long been known that the middle and lower Ottnangian beds are separated by a hiatus from the younger strata, and this break in deposition may simply have lasted longer than has been suggested up to now (see Reichenbacher et al. 2013, Sant et al. 2017). As a result, one must also consider environmental factors that might possibly have biased the ${ }^{87} \mathrm{Sr} /{ }^{86} \mathrm{Sr}$ signature obtained from the otolith samples studied here.

\section{Deviation of the ${ }^{87} \mathrm{Sr} /{ }^{86} \mathrm{Sr}$ signal owing to local inputs?}

Several factors can alter the $\mathrm{Sr}$ isotopic composition of ambient seawater. Among the most prominent are strong terrestrial and/or riverine run-off, which might well have affected the study area in SE Germany or indeed the whole of the Paratethys (see also Vennemann \& Hegner 1998, Kocsis et al. 2009). Thus, run-off and sediment input from the crystalline rocks of the Bohemian Massif or the Black Forest (see Pawellek et al. 2001) could have shifted the primary signal of Upper Marine Molasse seawater to more radiogenic values (Fig. 3). The opposite effect, i.e. a reduction in the magnitude of the ambient ${ }^{87} \mathrm{Sr} /{ }^{86} \mathrm{Sr}$ ocean signal, could have occurred when drainage areas were 
largely composed of limestones (such as the Mesozoic carbonates of the Alps or the Franconian Platform).

Mitterdorf is located very close to the coastal cliffs of the Bohemian Massif, which consist of Precambrian or Paleozoic granitic rocks with high ${ }^{87} \mathrm{Sr} /{ }^{86} \mathrm{Sr}$ values (e.g. Liew \& Hofmann 1988) (Fig. 1). Indeed, a direct influence of the Bohemian Massif has been documented for several localities close to Mitterdorf. Wenger (1987) showed that in Anderl, $8 \mathrm{~km}$ east of Mitterdorf, marine sands of the OMM are deposited directly on granites from the Bohemian Massif. He also described a granitic basement for the OMM at Oberschwärzenbach (6 km south of Mitterdorf) and Neustift (12 km northwest of Mitterdorf). Frieling et al. (2009) showed that the OMM sediments at Gurlan ( $5 \mathrm{~km}$ northeast of Mitterdorf) also directly overlie granitic deposits. This indicates that the early Ottnangian sediments of the SE German Molasse basin covered the crystalline rocks of the Bohemian Massif. The proximity of the study site Mitterdorf to the Bohemian Massif, together with strong fluviatile run-off, could explain why the Sr-based age signature obtained from the Mitterdorf otoliths studied here might be too low.

One of the largest rivers that flowed into the SE German Molasse Basin from the northwest during the Ottnangian was the Palaeo-Naab (Lemcke 1985, Kuhlemann \& Kempf 2002, Pippèrr \& Reichenbacher 2010) (Fig. 1). Today, 52\% of the Naab's catchment area consists of igneous rocks (Fichtelgebirge, Oberpfälzer Wald, i.e. Bohemian Massif), while $41 \%$ is made up of the carbonates of the Jurassic Franconian Platform, and its waters now have a ${ }^{87} \mathrm{Sr} /{ }^{86} \mathrm{Sr}$ ratio of 0.7144 (Pawellek et al. 2001). The rivers Regen and Ilz drain an area whose substratum is almost entirely igneous in character (94 and $98 \%$, respectively), and is largely derived from the Bohemian Massif (Fig. 1). This results in a shift towards relatively high $\mathrm{Sr}$ isotopic ratios $\left({ }^{87} \mathrm{Sr} /{ }^{86} \mathrm{Sr}=0.7147\right.$ and 0.7141 , respectively according to Pawellek et al. 2001) in the river water.

Due to the very low $\mathrm{Sr}$ concentration in river water (0.5-0.65 $\mu \mathrm{mol} / 1$, see Pawellek et al. 2001) compared to open marine $\mathrm{Sr}$ concentrations, an immense volume of river water would have been necessary to alter the primary $\mathrm{Sr}$ isotope signature of the Upper Marine Molasse Sea. However, for the early to middle Ottnangian time, such a high rate of river discharge from the Palaeo-Naab has actually been inferred from foraminiferal palaeoecology (Pippèrr \& Reichenbacher 2010). This high river discharge could have decreased the salinity of the surface water, which, together with the early Ottnangian transgression, could account for the anoxic bottom waters indicated by the foraminiferal assemblages (Pippèrr \& Reichenbacher 2010). Assuming that the early Ottnangian was generally characterized by high precipitation (and correspondingly high rates of river outflow), the salinity of the early
Ottnangian Molasse Sea could have been much lower than is generally assumed, which could explain the more radiogenic $\mathrm{Sr}$ isotopic compositions in its surface waters indicated by our new data (see also Bryant et al. 1995, Holmden et al. 1997). However, further studies are necessary to evaluate whether the salinity of the Upper Marine Molasse Sea was in fact relatively low.

\section{Comparison with previous $\mathrm{Sr}$ isotope data for the North Alpine Foreland Basin (NAFB)}

A single study has previously investigated $\mathrm{Sr}$ isotopes derived from the fossil otoliths of marine fishes from sediments in the NAFB (Pippèrr et al. 2007). That otolith sample originated from the middle Ottnangian OMM of the Simssee area in the central Molasse Basin (Fig. 1). The mean ${ }^{87} \mathrm{Sr} /{ }^{86} \mathrm{Sr}$ ratio obtained was $0.708606 \pm 0.000018$, which indicates an age of $17.8 \pm 0.3 \mathrm{Ma}$ based on the global Sr curve of Howarth \& McArthur (2003) (see Pippèrr et al. 2007) and on the latest version published by McArthur et al. (2012) (Fig. 3). Moreover, this age estimate also argues in favour of the assumption that the $\mathrm{Sr}$ isotope values in the present work are 'too young', because the Neuhofen Beds are lower Ottnangian and thus should be older than $17.8 \pm$ $0.3 \mathrm{Ma}$. Consequently, one can conclude that, in principle, otoliths as well as ostracods provide reliable records of the Sr isotopic composition of the ambient seawater for age determination, provided that relevant aspects of the local and regional geological setting are taken into consideration.

Analyses of phosphatic fossils like shark teeth (Vennemann \& Hegner 1998, Kocsis et al. 2009) have all yielded more radiogenic $\mathrm{Sr}$ ratios than expected for the corresponding ages when compared with the recent global $\mathrm{Sr}$ seawater curve (LOWESS 5 Fit) (McArthur et al. 2012) (Fig. 3). Kocsis et al. (2009) explained this offset, as discussed above, by invoking an erosional influence from crystalline rocks (e.g. Bohemian Massif or Black Forest), but in this context they also cite diagenetic overprinting and the poor preservation of the phosphatic material. Shark teeth from the OMM at Äpfingen (middle Ottnangian) produced $\mathrm{Sr}$ isotope ages of $16.8 \pm 1 \mathrm{Ma}$ on comparison with the $\mathrm{Sr}$ isotope evolution curve for the ocean after DePaolo (1986) (see Vennemann \& Hegner 1998). However, when the Sr signature from Äpfingen is compared with the recent global Sr evolution seawater curve (LOWESS 5 Fit) of McArthur et al. (2012), the derived age is about $14 \mathrm{Ma}$ (Fig. 3), which is much too young for the middle Ottnangian. Besides possible overprints due to diagenesis, multiple reworking of these phosphatic fossils could bias $\mathrm{Sr}$ age data from samples of shark teeth. Consequently, for the lower Miocene Upper Marine Molasse sediments in the S German Molasse Basin and Western and Central Paratethys, respectively, aragonitic or calcitic materials 


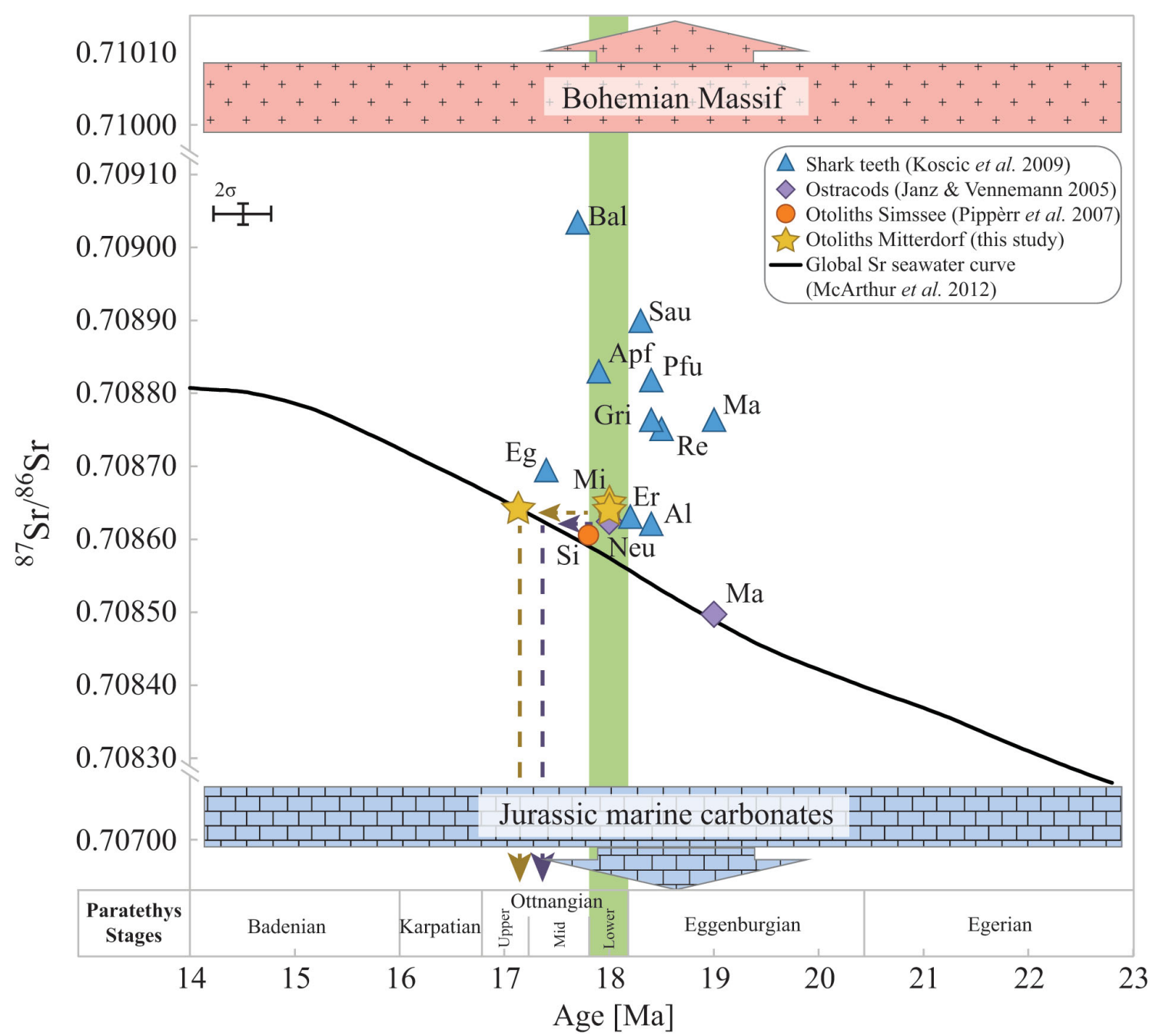

Figure 3. Distribution of the ${ }^{87} \mathrm{Sr} /{ }^{86} \mathrm{Sr}$ isotope ratios of the otoliths studied here, together with those of previously studied fossils from the $\mathrm{S}$ German Molasse Basin. The global seawater curve (LOWESS 5 fit) (McArthur et al. 2012) is shown in black and the corresponding Central Paratethys stages are indicated at the bottom (after Piller et al. 2007, Reichenbacher et al. 2013). For fossil localities, see Figure 1. The green bar highlights the lower Ottnangian (time of deposition of the Neuhofen Beds).

such as otoliths, ostracods or foraminifera (Pippèrr et al. 2007, Janz \& Vennemann 2005) would seem to provide much more reliable Sr-based age estimates than phosphatic fossils (Vennemann \& Hegner 1998, Kocsis et al. 2009). This assumption is additionally reinforced by a recent study on $\mathrm{Sr}$ isotopes from three fossil otoliths of middle Miocene age (Brzobohatý et al. 2016).

\section{Summary and conclusion}

We have analysed different fractions of otoliths from two fossil marine fish taxa (Diaphus and Coelorinchus) from the middle Burdigalian (lower Ottnangian) Neuhofen Beds at Mitterdorf. The study site is located in the SE German Molasse Basin, i.e. the westernmost Central Paratethys. For the first time, a leaching procedure was used to remove a mobile (non-primary) ${ }^{87} \mathrm{Sr} /{ }^{86} \mathrm{Sr}$ phase from the samples prior to $\mathrm{Sr}$ isotope analysis and age interpretation. Comparison of the $\mathrm{Sr}$ isotopic signatures from leached and not-leached otoliths strongly indicates that the leaching procedure is essential for the extraction of a valid ambient ${ }^{87} \mathrm{Sr} /{ }^{86} \mathrm{Sr}$ seawater signal from such fossils.

The otoliths from the Neuhofen Beds exhibited an ${ }^{87} \mathrm{Sr} /{ }^{86} \mathrm{Sr}$ ratio which, according to the global Sr evolution seawater curve (LOWESS 5 Fit) of McArthur et al. (2012), indicates an age of $17.1 \pm 0.3 \mathrm{Ma}$. However, this age is at least $0.6 \mathrm{Ma}$ too young when compared to previous age estimates based on biostratigraphic data. A possible reason for this apparent discrepancy is strong riverine or terrestrial run-off from the granitic rocks of the Bohemian Massif during the relevant interval, as has been suggested in previous work based on foraminiferal palaeoecology. This strong freshwater inflow would have delivered material 
from the granitic hinterland, thus shifting the Sr signature of the Molasse or Central Paratethys Sea towards more radiogenic (and thus 'too young') ${ }^{87} \mathrm{Sr} /{ }^{86} \mathrm{Sr}$ values.

Comparisons with previous studies of shark teeth, ostracods and otoliths from the S German Molasse Basin confirm that otoliths and ostracods constitute useful sources of $\mathrm{Sr}$ isotope data for age determination of marine successions, whereas shark teeth are less appropriate, possibly due to diagenetic overprint and multiple reworking. However, otoliths and ostracods used for age analysis must be carefully selected from marine settings without terrestrial or riverine influences.

\section{Acknowledgements}

We thank Jürgen Pollerspöck (Stephansposching, Germany) for providing the studied otolith samples, Florian Weitzel (Munich) for his help in otolith selection, and Martina Pippèrr (LMU Munich) for fruitful discussions and valuable support concerning the biostratigraphy of the Mitterdorf site. We also acknowledge Ernst Hegner (LMU Munich) for providing the facilities for the Sr isotope analyses as well as Laszlo Kocsis (Universiti Brunei Darussalam) for constructive discussions.

\section{References}

Abdul Aziz, H., Böhme, M., Rocholl, A., Prieto, J., Wijbrans, J.R., BACHTADSE, V. \& UlBig, A. 2010. Integrated stratigraphy and ${ }^{40} \mathrm{Ar} /{ }^{39} \mathrm{Ar}$ chronology of the early to middle Miocene Upper Freshwater Molasse in western Bavaria (Germany). International Journal of Earth Sciences 99, 1859-1886.

DOI 10.1007/s00531-009-0475-8

Allen, P.A., Mange-Rajetzky, M. \& Matter, A. 1985. Dynamic palaeogeography of the open Burdigalian seaway, Swiss Molasse Basin. Eclogae Geologicae Helvetiae 78, 351-381.

Bayon, G., German, C.R., Boella, R.M., Milton, J.A., Taylor, R.N. \& Nesbitt, R.W. 2002. An improved method for extracting marine sediment fractions and its application to $\mathrm{Sr}$ and Nd isotopic analysis. Chemical Geology 187, 179-199.

DOI 10.1016/S0009-2541(01)00416-8

Bryant, J.D., Jones, D.S. \& Mueller, P.A. 1995. Influence of Freshwater Flux on ${ }^{87} \mathrm{Sr} /{ }^{86} \mathrm{Sr}$ Chronostratigraphy in Marginal Marine Environments and Dating of Vertebrate and Invertebrate Faunas. Journal of Paleontology 69, 1-6. DOI 10.1017/S002233600002686X

Brzobohatý, R., Kalvoda, J., Frýda, J. \& Erban, V. 2016. Strontium isotope record of the Hygophum hygomii otoliths from the European middle Miocene. Geobios 49(5), 349-354. DOI 10.1016/j.geobios.2016.06.007

Cicha, I., Seneš, J. \& Tejkal, J. 1967. M3 (Karpatien). Die Karpatische Serie und ihr Stratotypus. Chronostratigraphie und Neostratotypen, Miozän der Zentralen Paratethys, 1, $1-312$.
Cohen, D.M., Inada, T., Iwamoto, T. \& Scialabba, N. 1990. Gadiform fishes of the world (Order Gadiformes). An annotated and illustrated catalogue of cods, hakes, grenadiers and other gadiform fishes known to date. FAO Fisheries Synopsis 125(10), 442.

DePaolo, D.J. 1986. Detailed record of the Neogene Sr isotopic evolution of seawater from DSDP Site 590B. Geology 14, 103-106.

DOI 10.1130/0091-7613(1986)14<103:DROTNS >2.0.CO;2

Doppler, G., Heissig, K. \& Reichenbacher, B. 2005. Zur Gliederung des Tertiärs im süddeutschen Molassebecken. Newsletters on Stratigraphy 41, 359-375. DOI 10.1127/0078-0421/2005/0041-0359

Frieling, D., Pippèrr, M., Schneider, S. \& Reichenbacher, B. 2009. Sedimentology and stratigraphy at the rocky coast of the upper Burdigalian Molasse Sea: a case study from Gurlan near Passau (SE Germany). Facies 55, 47-62.

DOI 10.1007/s10347-008-0161-5

Gradstein, F.M., OGG, J.G., Schmitz, M. \& OGG, G.M. (eds) The Geologic Time Scale 2012. 1176 pp. Elsevier, Amsterdam.

Grunert, P., Auer, G., Harzhauser, M. \& Piller, W.E. 2015. Stratigraphic constraints for the upper Oligocene to lower Miocene Puchkirchen Group (North Alpine Foreland Basin, Central Paratethys). Newsletters on Stratigraphy 48(1), 111-133. DOI 10.1127/nos/2014/0056

Grunert, P., Hinsch, R., Sachsenhofer, R.F., Bechtel, A., Ćorić, S., Harzhauser, M., Piller, W.E. \& Sperl, H. 2013. Early Burdigalian infill of the Puchkirchen trough (North Alpine Foreland Basin, Central Paratethys): facies development and sequence stratigraphy. Marine and Petroleum Geology 39,164-186. DOI 10.1016/j.marpetgeo.2012.08.009

Hagn, H., Malz, H., Martini, E., Weiss, W. \& Witt, W. 1981. Miozäne Vorland-Molasse Niederbayerns und Kreide von Regensburg. Exkursion G. Geologica Bavarica 82, 263-286.

Holmden, C., Creaser, R.A. \& Muehlenbachs, K. 1997. Paleosalinities in ancient brackish water systems determined by ${ }^{87} \mathrm{Sr} /{ }^{86} \mathrm{Sr}$ ratios in carbonate fossils: A case study from the Western Canada Sedimentary Basin. Geochimica et Cosmochimica Acta 61, 2105-2118. DOI 10.1016/S0016-7037(97)00073-2

Horwitz, E.P., Chiarizia, R. \& DieTz, M.L. 1992. A novel strontium-selective extraction chromatographic resin. Solvent Extraction Ion Exchange 10, 313-336.

Howarth, R.J. \& McArthur, J.M. 2003. SIS LOOK-UP TABLE, Version 4: 08/03. - Received by personal communication.

Hulley, P.A. 1986. Myctophidae, 282-321. In Smith, M.M. \& Heemstra, P.C. (eds) Smiths' sea fishes. Springer Verlag, Berlin.

INGRAM, B.L. \& SlOAN, D. 1992. Strontium isotopic composition of estuarine sediments as paleosalinity-paleoclimate indicator. Science 255, 68-72. DOI 10.1126/science.255.5040.68

Janz, H.V. \& Vennemann, T.W. 2005. Isotopic composition $(\mathrm{O}, \mathrm{C}, \mathrm{Sr}$, and $\mathrm{Nd})$ and trace element ratios $(\mathrm{Sr} / \mathrm{Ca}, \mathrm{Mg} / \mathrm{Ca})$ of Miocene marine and brackish ostracods from North Alpine Foreland deposits (Germany and Austria) as indicators for palaeoclimate. Palaeogeography, Palaeoclimatology, 
Palaeoecology 225, 216-247.

DOI 10.1016/j.palaeo.2005.06.012

Jones, C.E., Jenkyns, H.C. \& Hesselbo, S.P. 1994. Strontium isotopes in Early Jurassic seawater. Geochimica et Cosmochimica Acta 58, 1285-1301. DOI 10.1016/0016-7037(94)90382-4

Kennedy, B.P., Blum, J.D., Folt, C.L. \& Nislow, K.H. 2000. Using natural strontium isotopic signatures as fish markers: methodology and application. Canadian Journal of Fisheries and Aquatic Sciences 57, 2280-2292. DOI 10.1139/f00-206

Kennedy, B.P., Klaue, A., Blum, J.D., Folt, C.L. \& Nislow, K.H. 2002. Reconstructing the lives of fish using Sr isotopes in otoliths. Canadian Journal of Fisheries and Aquatic Science 59, 925-929. DOI 10.1139/f02-070

Kocsis, L., Vennemann, T.W., Hegner, E., Fontignie, D. \& TÜTKEn, T. 2009. Constraints on Miocene oceanography and climate in the Western and Central Paratethys: O-, Sr-, and Nd-isotope compositions of marine fish and mammal remains. Palaeogeography, Palaeoclimatology, Palaeoecology 271, 117-129. DOI 10.1016/j.palaeo.2008.10.003

Kuhlemann, J. \& KempF, O. 2002. Post-Eocene evolution of the North Alpine Foreland Basin and its response to Alpine tectonics. Sedimentary Geology 152, 45-78. DOI 10.1016/S0037-0738(01)00285-8

LeMCKe, K. 1985. Flußfracht von Ur-Main und Ur-Naab in der Schweiz und im deutschen Molassebecken. Bulletin der Vereinigung Schweizerischer Petroleum-Geologen und -Ingenieure, 51, 13-21.

LeMCKe, K. 1988. Geologie von Bayern. - I. Teil: Das bayerische Alpenvorland vor der Eiszeit - Erdgeschichte, Bau, Bodenschätze. 175 pp. E. Schweizerbart, Stuttgart.

Liew, T.C. \& Hofmann, A.W. 1988. Precambrian crustal components, plutonic associations, plates environments of the Hercynian Fold Belt of central Europe: indications from a Nd and Sr isotopic study. Contributions to Mineralogy and Petrology 98, 129-138. DOI 10.1007/BF00402106

McArthur, J.M., Howarth, R.J. \& Shields, G.A. 2012. Strontium Isotope Stratigraphy, 127-144. In GradsteIn, F.M., OGG, J.G., Schmitz, M. \& OGG, G.M. (eds) The Geologic Time Scale 2012. Elsevier, Amsterdam.

PAlmer, M.R. \& EDMOND, J.M. 1989. The strontium isotope budget of the modern ocean. Earth and Planetary Science Letters 92, 11-26. DOI 10.1016/0012-821X(89)90017-4

Papp, A., Rögl, F. \& Seneš, J. (eds) 1973. Miozän M2 Ottnangien. Die Innviertler, Salgotatjaner, Bantapusztaer Schichtengruppe und die Rzehakia Formation, Chronostratigraphie und Neostratotypen, Miozän der zentralen Paratethys. 841 pp. Slovenská Akadémia Vied, Bratislava.

Pawellek, F., Frauenstein, F. \& Veizer, J. 2001. Hydrochemistry and isotope geochemistry of the Danube River. Geochimica et Cosmochimica Acta 66, 3839-3854. DOI 10.1016/S0016-7037(01)00880-8

Piller, W.E., Harzhauser, M., \& Mandic, O. 2007. Miocene Central Paratethys stratigraphy - current status and future directions. Stratigraphy 4, 151-168.

PIPPÈRR, M. 2011. Characterisation of Ottnangian palaeoenvironments in the North Alpine Foreland Basin using benthic foraminifera - a review on the Upper Marine Molasse of Southern Germany. Marine Micropaleontology 79, 80-99. DOI 10.1016/j.marmicro.2011.02.002

PipPÈRR, M. \& ReICHenbacher, B. 2009 Biostratigraphy and paleoecology of benthic foraminifera from the Eggenburgian "Ortenburger Meeressande" of southeastern Germany (Early Miocene, Paratethys). Neues Jahrbuch für Geologie und Paläontologie, Abhandlungen 254, 41-61.

DOI 10.1127/0077-7749/2009/0003

PipPÈRr, M. \& Reichenbacher, B. 2010. Foraminifera from the borehole Altdorf (SE Germany): Proxies for Ottnangian (early Miocene) palaeoenvironments of the Central Paratethys. Palaeogeography, Palaeoclimatology, Palaeoecology 289, 62-80. DOI 10.1016/j.palaeo.2010.02.009

Pippèrr, M. \& Reichenbacher, B. 2017. Late Early Miocene palaeoenvironmental changes in the North Alpine Foreland Basin. Palaeogeography, Palaeoclimatology, Palaeoecology 468, 485-502. DOI 10.1016/j.palaeo.2017.01.002

Pippèrr, M., Reichenbacher, B., Kirscher, U., Sant, K, HANEBECK, H. (in press). The middle Burdigalian in the North Alpine Foreland Basin (Bavaria, SE Germany) - A lithostratigraphic, biostratigraphic and magnetostratigraphic re-evaluation. Newsletter Stratigraphy.

Pippèrr, M., Reichenbacher, B., Witt, W. \& Rocholl, A. 2007. The Middle and Upper Ottnangian of the Simssee area (SE Germany): micropalaeontology, biostratigraphy and chronostratigraphy. Neues Jahrbuch für Geologie und Paläontologie, Abhandlungen 245, 353-378.

DOI 10.1127/0077-7749/2007/0245-0353

PopPER, A.N. 1976. Ultrastructure of the auditory regions in the inner ear of the lake whitefish. Science 192, 1020-1023. DOI 10.1126/science.1273585

Popper, A.N., Ramcharitar, J. \& CAmPana, S.E. 2005. Why otoliths? Insights from inner ear physiology and fisheries biology. Marine and Freshwater Research 56, 497-504. DOI 10.1071/MF04267

Qing, H., BARnes, C.R., Buhl, D. \& Veizer, J. 1998. The strontium isotopic composition of Ordovician and Silurian brachiopods and conodonts: relationships to geological events and implications for coeval seawater, Geochimica et Cosmochimica Acta 62, 1721-1733.

DOI 10.1016/S0016-7037(98)00104-5

Reichenbacher, B., Krijgsman, W., Lataster, Y., Pippèrr, M., van BaAk, C.G.G., Chang, L., Kälin, D., Jost, J., Doppler, G., Jung, D., Prieto, J., Abdul Aziz, H., Böhme, M., Garnish, J., Kirscher, U. \& Bachtadse, V. 2013. A new magnetostratigraphic framework for the Lower Miocene (Burdigalian/Ottnangian, Karpatian) in the North Alpine Foreland Basin. Swiss Journal of Geoscience 106, 309-334. DOI 10.1007/s00015-013-0142-8

Reinhardt, E.G., Fitton, R.J. \& Schwarcz, H.P. 2003. Isotopic $(\mathrm{Sr}, \mathrm{O}, \mathrm{C})$ indicators of salinity and taphonomy in marginal marine environments. Journal of Foraminiferal Research 33, 262-272. DOI 10.2113/33.3.262

Roetzel, R., De Leeuw, A., Mandic, O., Marton, E., Nehyba, S., Kuiper, K., Scholger, R. \& Wimmer-Frey, I. 2014. Lower Miocene (upper Burdigalian, Karpatian) volcanic ash-fall at 
the south-eastern margin of the Bohemian Massif in Austria New evidence from 40Ar/39Ar-dating, palaeomagnetic, geochemical and mineralogical investigations. Austrian Journal of Earth Sciences 107, 2-22.

Sant, K., Kirscher, U., Reichenbacher, B., Pippèrr, M., Jung, D., Doppler, G. \& Krijgsman, W. 2017. Late Burdigalian sea retreat from the North Alpine Foreland Basin: new magnetostratigraphic age constraints. Global and Planetary Change 152, 38-50. DOI 10.1016/j.gloplacha.2017.02.002

SteIGER, R.H. \& JÄGER, E. 1977. Subcommission on geochronology: convention on the use of decay constants in geo- and cosmochronology. Earth and Planetary Science Letters 36, 359-362. DOI 10.1016/0012-821X(77)90060-7

Steininger, F., Rögl, F. \& Martini, E. 1976. Current Oligocene/Miocene biostratigraphic concept of the Central Paratethys (Middle Europe). Newsletters on Stratigraphy 4, 174-202. DOI 10.1127/nos/4/1976/174

Vennemann, T.W. \& Hegner, E. 1998. Oxygen, strontium and neodymium isotope composition of shark teeth as a proxy for the palaeoceanography and palaeoclimatology of the Miocene northern Alpine Paratethys. Palaeogeography, Palaeoclimatology, Palaeoecology 142, 107-121.

DOI 10.1016/S0031-0182(98)00062-5

Vennemann, T.W., Hegner, E., Cliff, G. \& Benz, G.W. 2001. Isotopic composition of recent shark teeth as a proxy for environmental conditions. Geochimica et Cosmochimica Acta 65, 1583-1599. DOI 10.1016/S0016-7037(00)00629-3

Walther, B.D. \& Thorrold, S.R. 2006. Water, not food, contributes the majority of strontium and barium deposited in the otoliths of a marine fish. Marine Ecology Progress Series 311, 125-130. DOI 10.3354/meps311125

Wenger, W.F. 1987. Die Foraminiferen des Miozäns der bayerischen Molasse und ihre stratigraphische sowie paläogeographische Auswertung. Zitteliana 16, 173-340.

WiтT, W. 1967. Ostracoden der bayerischen Molasse (unter besonderer Berücksichtigung der Cytherinae, Leptocytherinae, Trachyleberidinae, Hemicytherinae und Cytherettinae). Geologica Bavarica 57, 1-120. 